\title{
Precarious Positions: Native Hawaiians \\ and US Federal Recognition
}

\author{
J Kēhaulani Kauanui
}

The conspirators, having actually gained possession of the machinery of government, and the recognition of foreign ministers, refused to surrender their conquest. So it happens that, overawed by the power of the United States to the extent that they can neither themselves throw off the usurpers, nor obtain assistance from other friendly states, the people of the Islands have no voice in determining their future, but are virtually relegated to the condition of the aborigines of the American continent.

HRH LILI'UOKALANI, Hawaii’s Story by Hawaii's Queen

Queen Lili'uokalani's words of anger and frustration at the raw power used by the United States in relation to Native Hawaiian people during the late nineteenth century resonate strongly with twenty-first century indigenous resistance to attempts to reduce Native Hawaiians to the political status of American Indians. ${ }^{1}$ A proposal currently before the US Congress would recognize a Native Hawaiian nation within the confines of US federal policy for Native Americans. Beginning in the 106th US Congress in 2000 and continuing through the present, Senator Daniel Akaka, a Democrat from the State of Hawai'i, introduced this federal legislation, which proposes to recognize Hawaiians as an indigenous people who have a "special relationship" with the United States and thus a right to limited self-determination. Passage of the bill would lay the foundation for a nation-within-a-nation model of self-governance and would redefine Native Hawaiians' current legal status in ways that parallel the political

The Contemporary Pacific, Volume I7, Number I, I-27

(C) 2005 by University of Hawai'i Press 
process used to subjugate American Indian tribal nations. US law has defined tribal sovereignty, already a contested concept, as the right of tribes as "domestic dependent nations" to exercise limited self-determination and the right to self-government. Federally recognized tribes have the right to assert jurisdiction over their people and their land; define their own tribal membership criteria; create tribal legislation, law enforcement, and court systems; and tax their own citizens.

This essay examines the impetus for the federal recognition proposal. It also explores a range of historical and legal issues that shed light on the multiple claims constituting the complex terrain of Hawaiian sovereignty politics. The proposal for federal recognition is extremely controversial for several reasons. For one, it was initiated by a US federal representative, not the Native Hawaiian people, ${ }^{2}$ as a remedy against new political developments in the courts that threaten current US federal funding and programs for Native Hawaiians. Second, numerous Hawaiian political organizations oppose what they see as an effort to contain Hawai'i's independence claim under international law. Third, there is local opposition, on the part of non-Hawaiian residents of Hawaici, to this form of recognition. And fourth, there is rampant opposition in the US Senate from Republicans who condemn this proposal because it would extend to Native Hawaiians distinct rights. However, their conservative antagonism is slowly shifting to qualified support.

I first provide a historical overview of the events that impact the current situation and provide a legal basis for US federal recognition. Then I discuss a particular set of contemporary conditions that serve as key elements in catalyzing widespread support for federal recognition-namely, the implications of the recent US Supreme Court ruling in Rice $v$ Cayetano (2000) and subsequent legal challenges to Native Hawaiian programs and funding by the US government. I also discuss the broader context for recognizing Native Hawaiians as an indigenous people within the United States-stemming from a much longer history of incorporating Native Hawaiians within the definition of "Native American." I then highlight some of the difficulties with the promise of federal recognition as a solution to "the Hawaiian problem" by looking at lessons from Indian Country, Native Alaska, and the Pacific-especially the US unincorporated territories. In conclusion, I delineate the legal claims that exceed the US federal model and point to the alternative activist strategies Native Hawaiians and others in Hawai'i are pursuing. 


\section{A History of Illegality}

A series of critical historical events provide the backdrop for understanding the complex terrain of Hawaiian sovereignty politics. In I893, US Minister of Foreign Affairs John L Stevens, with the support of a dozen white settlers, organized a coup d'etat and overthrew Queen Lili'uokalani, the monarch of the Kingdom of Hawai'i (Trask 1993; Kent I993; Fuchs I96I). The queen yielded her authority under protest, as she was confident that the US government and President Harrison would endeavor to undo the actions led by one of its ministers. Within months, however, Harrison was out of office and Grover Cleveland became the next US president. Eventually, after sending an investigator on the matter, Cleveland declared the action under Stevens an "act of war" and acknowledged that the coup, backed by US marines, had been unlawful and should be undone. Specifically, he recommended that the provisional government (made up of those who had orchestrated the overthrow) should step down - but they refused. Cleveland did not compel them to do so and thus did not assist in restoring formal recognition to the queen. In the meantime, the provisional government established the Republic of Hawai' $i$ on 4 July I 894, with Sanford Ballard Dole as president. As the de jure government, asserting jurisdiction over the entire Island archipelago, this group seized roughly I.8 million acres-Hawaiian Kingdom government and Crown lands (Coffman I998). In I898, when the United States illegally annexed Hawai'i, the republic then ceded these same lands, under the condition that they be held in trust for the inhabitants of the Hawaiian Islands (Silva 1998; Coffman 1998; Hasager and Friedman 1994).

In her groundbreaking research, Noenoe K Silva has brought to light a powerful resistance history that reveals broad-based Hawaiian opposition to US annexation-opposition so strong that it successfully defeated a proposed treaty of annexation in 1897 (Silva I998, 2004). Hawaiians organized into two key nationalist groups-Hui Aloha 'Āina and Hui Kālai'aina-each of which submitted petitions representing the vast majority of Hawaiian people alive in Hawai'i at the time. In those peti-

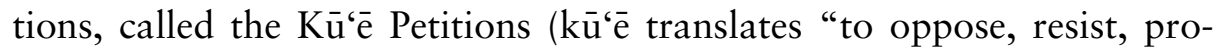
test"), Hawaiians clearly stated their opposition to becoming part of the United States in any way. The US Senate accepted these petitions but found it impossible to secure the two-thirds majority vote required in the 
Senate for a treaty. However, this did not stop the US government. During US President McKinley's term, the Republic of Hawai'i and other proannexationists proposed a joint resolution of Congress, which required only a simple majority in both houses-and so the Newlands Resolution passed in 1898.3 Thus, the United States did not annex the Hawaiian Islands by treaty, as required under customary international law at the time. Furthermore, annexation of Hawai'i as a new territory (and not a state) violated the US Constitution. ${ }^{4}$

To many outsiders today, the history of the illegal overthrow and annexation may seem irrelevant, given the fact that Hawai' $i$ is counted as one of the fifty states of the United States of America. But as many Hawaiian activists point out, statehood is also contestable. Like many other colonial territories, in 1946 Hawai'i was inscribed on the United Nations list of non-self-governing territories. As such, Hawai'i was eligible for decolonization under international law. However, the United States-in clear violation of UN policy and international law-predetermined statehood as the status for Hawai'i. The US federal government approved a statehood bill for Hawai'i based on a vote conducted by the colonial territorial government. Yet, Hawai'i was entitled to a plebiscite as mandated by the UN Charter, Chapter XI, Article 73, and General Assembly Resolution 742 , regarding the process of non-self-governing territories pursuing self-determination and a form of self-government. In other words, a plebiscite should have been undertaken with UN supervision, rather than determined by an internal administrating body of the US government. ${ }^{5}$ After elections for state senators and one representative, the United States admitted Hawai' $i$ as a state of the union on 2I August I959. In turn, the US representative reported to the UN secretary-general that Hawai'i had become the fiftieth state and requested that it be taken off the list of nonself-governing territories, a major step back from the process of restoring national sovereignty.

\section{Basis for Federal Recognition}

There are two key legal bases for the argument supporting federal recognition for Native Hawaiians: the "Apology Resolution” (Public Law I03I 50 ) regarding the 1893 overthrow, passed by Congress in I993; and the Hawaiian Homes Commission Act of 1920. Both the resolution and the act are cited in any legal genealogy affirming the US obligation to Native Hawaiian people. Although it contains no mention of the annexation, the 
Apology Resolution acknowledges US complicity in the overthrow of Queen Lili'uokalani and the constitutional monarchy. Besides accounting for the events that led to the US-backed coup, the resolution also acknowledges that "the indigenous Hawaiian people never directly relinquished their claims to their inherent sovereignty as a people or over their national lands to the United States, either through their monarchy or through a plebiscite or referendum." ${ }^{6}$ Importantly, this resolution defines "Native Hawaiian" inclusively as "any individual who is a descendent of the aboriginal people who, prior to $\mathrm{I} 778$, occupied and exercised sovereignty in the area that now constitutes the State of Hawaii.” Although the apology includes a disclaimer at the very end, stating that nothing contained can be used to settle a case against the United States, it still constitutes a finding of fact. The other legal basis for federal recognition is the Hawaiian Homes Commission Act of 1920, approved by the US Congress in I92 I, which allotted approximately 200,000 acres of land, with ninety-nine-year lease provisions, to those who qualify as "native Hawaiians." In this case, "native Hawaiians" are defined as "descendants with at least one-half blood quantum of individuals inhabiting the Hawaiian Islands prior to I778." 7 These allotted lands were formerly part of the Crown and government lands of the Kingdom of Hawai'i. The Hawaiian Homes Commission Act was originally conceived as a Native rehabilitation project for the Hawaiian population, which had been experiencing dramatic depopulation linked to colonial urbanization. The act has been cited as evidence that the US government already acknowledged that one class of Hawaiians (those with 50 percent or more blood quantum) has entitlements that parallel those of American Indians (Kauanui 1999). The act also arguably institutionalized a trust agreement, constituting a special legal relationship.

As early as 1903, the US federal government passed legislation acknowledging the indigenous people of Hawai' $i$, and currently over I 60 federal statutes address the conditions of Native Hawaiians (Inouye 2003). Since the I970s, in the midst of a thriving Hawaiian rights movement, the US Congress has enacted numerous special provisions of law for the benefit of Native Hawaiians in the areas of health, education, labor, and housing. Thus it could be argued that the US Congress has already recognized that a special relationship exists between the United States and the Native Hawaiian people. The US Congress extended to Native Hawaiians the same rights and privileges accorded to American Indian, Alaska Native, Inuit, and Aleut communities in the Native American Programs Act of 
1974. This act also includes American Samoan Natives, and indigenous peoples of Guam, the Commonwealth of the Northern Mariana Islands, and the Republic of Palau-all designated as "Native American Pacific Islanders." And Native Hawaiians are also included in the American Indian Religious Freedom Act, National Museum of the American Indian Act, Native American Graves Protection and Repatriation Act, National Historic Preservation Act, and Native American Languages Act. ${ }^{8}$ In addition, there are several federal acts specific to Native Hawaiians, comparable to those providing for American Indians and Alaskan Natives, such as the Native Hawaiian Health Care Act and the Native Hawaiian Education Act. ${ }^{9}$ Whether all this legislation qualified Native Hawaiians as politically analogous to American Indians was a key question brought before the US Supreme Court in I999 and in subsequent challenges to Hawaiian rights to state and federal funding and indigenous-specific institutions, such as the Office of Hawaiian Affairs (онA) and the Department of Hawaiian Home Lands (DHHL).

\section{Rice $V$ Cayetano and the Context of Continuous Anti-Hawailan Assault}

The US Supreme Court ruling in the case of Rice $v$ Cayetano in February 2000 served as the central impetus for the proposal regarding federal recognition of Hawaiians. At stake in the Rice case were restricted elections for OHA trustees, along with the very existence of the Office of Hawaiian Affairs. Prior to the court ruling, participation in OHA elections was restricted to Native Hawaiians, of any Hawaiian ancestry, who resided in Hawai' $i$. Harold F Rice, a fourth-generation white resident of Hawai' $i$, was denied the right to vote because he is not Hawaiian by any statutory definition (he is neither "native Hawaiian" nor "Native Hawaiian"). The Office of Hawaiian Affairs, established in 1978 , is governed by a nine-member elected board of trustees and holds title to all real or personal property set aside or conveyed to it through the state Admission Act of I959 as part of the Ceded Public Lands Trust. It is also meant to hold the income and proceeds derived from a portion of a trust for "native Hawaiians" as defined in the Hawaiian Homes Commission Act and granted to the State of Hawai' $i$ at the time it was admitted to the union in I959 (MacKenzie I99I). As the plaintiff, Rice charged that both the trust managed by the office and the OHA voting provisions were racially discriminatory and violated the Fourteenth and Fifteenth Amendments to 
the US Constitution, which, respectively, are meant to provide equal protection, and to guarantee that the right of citizens to vote shall not be denied or abridged on account of race, color, or previous condition of servitude. But even though the trust itself is for the benefit of "native Hawaiians," the US Supreme Court's majority opinion decreed that the state's electoral restriction enacted race-based voting qualifications and thereby violated the Fifteenth Amendment.

In Rice $v$ Cayetano, Hawaiians were in a fraught position, with no direct voice in the case, even though it was central to Hawaiian concerns. ${ }^{10}$ Then-Governor Cayetano, notorious for his anti-Hawaiian veto power, was held accountable for the OHA voting practices because the office is a state agency. Still, the State of Hawai'i argued that the oHA limitation on the right to vote was based not on race but on the unique status of Hawaiian people in light of the state's trust obligations. Thus the limitation on the right to vote for the OHA trustees was based on a legal classification defining those people who are the beneficiaries of the trust. But because neither the US federal government nor the US Supreme Court recognizes Hawaiians collectively as a sovereign entity, the State of Hawai'i maintained that the voting classification was rationally tied to its requirement to uphold a congressional requirement-in other words, because the United States has a "special relationship" with and obligation to "native Hawaiians" stemming from the Hawaiian Homes Commission Act of $1920 .{ }^{11}$ Thus the defense in the Rice case rested on the claim that Congress has the power to enter into special trust relationships with indigenous peoples-a power that is not confined to tribal Indians-and that the state "stood in for" the United States with regard to land claims and related entitlements. ${ }^{12}$ The last part of this argument seemed most threatening to the US Supreme Court. However, these state obligations to Hawai'i's indigenous people did not convince the Supreme Court of the unique political situation of Hawaiians, a status that may have justified the exclusive OHA election process.

Favoring Rice, the majority Supreme Court opinion based its ruling on three major findings. First, the Office of Hawaiian Affairs was understood only as an arm of the state and not as a mechanism to fulfill the trust commitments delegated to the state by the federal government. So, because the OHA trustee elections are administered by the state rather than by a separate quasi-sovereign body (such as a federally recognized tribal government), the Fifteenth Amendment applies. Second, the court found that the limited voting franchise failed to comply with the Fifteenth 
Amendment. Third, it was not clear to the court that the voting classification was symmetrical with the beneficiaries of the programs that office administers; while the bulk of funds appear to be designated for "native Hawaiians" (as per the 50-percent rule), "Native Hawaiians" who reside in the state were also allowed to vote in the oHA elections. Thus, in the end, the court identified what it saw as an asymmetrical relationship between the Hawaiian-specific voting process and the beneficiaries of the trust. ${ }^{13}$ In the end, they declared that the OHA voting restrictions violated the Fifteenth Amendment.

To some, the Rice case may seem marginal in relation to the overall political climate in the United States. Yet, Theodore Olsen-well known for his legal representation of the current US president in Bush $v$ Gore (2000), and now serving as US solicitor general-was also the legal counsel for Rice. And Rice himself, in pursuing his role as the plaintiff, was financed by the Campaign for a Color-Blind America, Robert Bork, Americans against Discrimination and Preferences, the United States Justice Foundation, the Center for Equal Opportunity, the New York Civil Rights Coalition, and the Pacific Legal Foundation-all of which submitted legal briefs on his behalf. These extremely conservative right-wing think tanks have been central in a nationwide attack on affirmative action and other civil rights gains in the United States. The case also implicates political standing that exceeds these rights.

In addition, the ruling in Rice raises various questions about the constitutional rights of residents in the US insular territories, indicating that the Rice case has implications beyond the Hawaiian situation. ${ }^{14}$ For example, as Rice $v$ Cayetano was first heard before the US Court of Appeals, Congressman Faleomavaega from American Sàmoa noted that the ruling not only put the OHA elections in jeopardy but could also potentially affect the Samoan system of land tenure and chiefly titles. Prior to the decision, Faleomavaega noted, "Should the Supreme Court rule against the Native Hawaiians and hold that this US citizen was being discriminated against, the decision will have far-reaching implications for American Samoa's future-as this would allow any US citizen living in American Samoa to challenge American Samoa's laws." Further, he pointed out, "This raises my concern because legal scholars in the US do not consider our 'treaties' with the US to be 'treaties' in the technical sense, but 'deeds of cession,' which are considered of lesser authority than the US Constitution" (PIR I999). Therefore, any rights seen as privileging Samoans over other US 
citizens residing in American Sāmoa are vulnerable to constitutional challenges of racial discrimination.

The majority opinion in Rice $v$ Cayetano did not rule on the Fourteenth Amendment and thus did not affect the trust that the Office of Hawaiian Affairs is meant to manage. Nevertheless, the ruling has laid the essential groundwork for further assaults on Hawaiian lands and people, and indeed, several more lawsuits are now in motion. These new cases threaten the existence of all Hawaiian-specific funding sources and institutions, including the Office of Hawaiian Affairs; all federal funds for Hawaiian health, education, and housing; and the state Department of Hawaiian Home Lands and the lands it manages. Plaintiffs charge that these institutions are racially discriminatory because they violate the US Constitution's equal-protection clause.

These suits have led to increased political tensions in the Islands. In March 2002, a group of Hawai'i residents tried to stop state spending for programs offered by the Office of Hawaiian Affairs and the Hawaiian Homes Commission, though US District Judge Susan Oki Mollway denied a temporary restraining order requested by the group (Omandam 2002). Among the sixteen plaintiffs-Earl F Arakaki, Evelyn C Arakaki, Edward U Bugarin, Sandra P Burgess, Patricia Carroll, Robert M Chapman, Brian L Clarke, Michael Y Garcia, Roger Grantham, Toby M Kravet, James I Kuroiwa Jr, Fran Nichols, Donna M Scaff, Jack H Scaff, Allen Teshima, and Thurston Twigg-Smith-are state politicians and direct descendants of the first missionaries. They are currently challenging the constitutionality of both agencies because of allegations that their "race-based programs" discriminate against non-Hawaiians. Still, even while the judge denied their immediate request, the plaintiffs had standing to go forward with their lawsuit because, as taxpayers, they can challenge the use of state money to fund OHA and DHHL programs. The plaintiffs asked that the state stop spending state tax revenues for both programs. By March 2003 the case was filed in federal court on their behalf.

Shortly after the case was filed, in November 2003, District Judge Mollway dismissed the state Department of Hawaiian Home Lands/Hawaiian Homes Commission and the US federal government as parties to the lawsuit. Mollway ruled that the plaintiffs could not challenge the federal requirements for the Hawaiian Home Lands program because, based on a recent Ninth US Circuit Court of Appeals ruling, the plaintiffs would have to challenge federal law to challenge the corresponding state law. In 
her ruling Mollway noted, "State taxpayer standing is too limited to permit a challenge to a federal law and therefore does not allow plaintiffs to challenge the Hawaiian Home Lands lease program, which is mandated by both state and federal law" (quoted in Barayuga 2003). Some feel that the agency's dismissal from the lawsuit validates its legal standing. Now, the Office of Hawaiian Affairs is the sole remaining defendant in the lawsuit. According to Jon Van Dyke, one of the attorneys representing the office, it should also be dismissed from the case because it was also established pursuant to the Admission Act of 1959 for the State of Hawai'i (Barayuga 2003).

$\mathrm{H}$ William Burgess, attorney for the plaintiffs, said "that when considering a motion to dismiss for lack of standing, the court is required to take the plaintiffs' allegations as true and to construe it in favor of the plaintiffs" (Barayuga 2003). In his estimation, the court basically disregarded that precedent and made what amounted to factual determinations: "She says the Admissions Act doesn't have any causal connection to the taxpayer injury that the plaintiffs are suffering, and that's just contrary to the law" (quoted in Barayuga 2003). Some speculate that a person who applied for a Hawaiian Home Lands lease and was turned down solely because he or she was not Native Hawaiian could mount a more effective challenge. In other words, plaintiffs could apply for Hawaiian Homes leases, be turned down because they do not meet the 50-percent blood criterion for leasing eligibility, and then have standing to continue their racial discrimination lawsuit. Hawaiian activist Isaac Harp has recommended that OHA trustees begin work on amending the requirements for the Hawaiian Home Lands program and the Office of Hawaiian Affairs, to benefit the descendants of citizens of the nation prior to I 7 January I 893 who were not of Hawaiian ancestry but were nonetheless Hawai'i nationals under the kingdom. Utilizing an occupation analysis rather than a colonial analysis in the case of Hawai'i, Harp has suggested, "would eliminate the racist component because the issue is one of nationality not race" (e-mail to the Hawaii-Independence listserve, 8 Feb 2004). Although this strategy affirms and promotes the sovereignty of the Hawaiian Kingdom, which allowed for citizenship without regard for race, the promotion of a color-blind agenda neglects the long history of US policies directed specially at Native Hawaiians, which worked to hasten both dispossession and assimilation.

Within this context of legal assault, where any indigenous-specific program is deemed racist, many Hawaiians and their allies support Senator 
Akaka's proposal for federal recognition. To most, the bill is understood as a protective measure against such lawsuits. The bill originated in March 2000, just one month after the ruling in Rice, when Hawai'i's congressional delegation formed a Task Force on Native Hawaiian Issues, chaired by Senator Akaka. As its immediate goal, the task force aimed to clarify the political relationship between Hawaiians and the United States through the US Congress. Senator Akaka has described the proposal as the reconciliation legislation he first tried to spearhead over a decade ago, which at the time amounted to the Apology Resolution. Now his goals have different implications. Beginning in 2000, during the I06th US Congress, the senator introduced federal legislation that proposes to recognize Hawaiians as indigenous people who have a "special relationship" with the United States and thus a right to self-determination under federal law. Passage of the bill would lay the foundation for a nation-withina-nation model of self-governance, parallel to that of recognized American Indian tribes. Because federal recognition would redefine Hawaiians as a political entity, challenges of "racial" distinctions would likely be moot in terms of equal protection under the US Constitution. ${ }^{15}$ Federal protection is now being sold to Hawaiians as a defense against average citizens who challenge the Hawaiian trusts that the United States never upheld in the first place, trusts that are based on the theft of a nation. ${ }^{16}$

These political misdeeds continue to go unquestioned and have problematic implications for the future, as can be seen even in the process of drafting and putting forth the proposal. Not only has the proposal involved little Hawaiian participation in its development, but it has also served as a political football, blocked by conservatives. For example, only for the very earliest draft of the bill (s 2899), back in 2000, were hearings held in Hawai' $i$, and only in Honolulu. Despite widespread opposition to the bill, s 2899 was introduced in the 106th Congress, where it did not survive the Senate Committee on Indian Affairs. The next version of the bill (s 8I) was soon introduced but did not pass. After major revision, the bill was reintroduced in the ro7th Congress, designated as S 746. In December 200I, Republicans opposing the bill pulled it out of a defense spending measure, where it had been slipped in without the knowledge of the Hawaiian people. Subsequently, the bill was drafted yet again, ostensibly to make it more palatable to right-wing opponents in the US Senate, who already construe any set of self-governing rights for indigenous peoples as "racial preferences." Those changes were reflected in the next bill, S I783, which also did not pass due to Republican opposition in the Sen- 
ate. In February 2003, during the I08th Congress, the proposal reemerged as $\mathrm{S} 344$, a bill that was very much like the one immediately before. But conservative forces in the Senate continue to refuse support for the measure, especially since the Bush administration has yet to take a position on the legislation (Viotti 2003a).

All throughout 2003 , S 344 was revised in ways designed to further limit Hawaiian claims and appeal to right-wing interests. On I 2 May 2003, the Hawai'i congressional delegation agreed to make revisions to the recognition bill. Some of these revisions are: (I) a federal Office for Native Hawaiian Relations would compile and maintain a roll of Hawaiians willing and eligible to participate in a new Hawaiian government; (2) people who felt they had been excluded from the roll could appeal to the US Department of the Interior; (3) Hawaiians on the roll could form an interim governing council to develop the structure and scope of a new government; and (4) the interim council would disband once elected officers of a new government take office (DePledge 2003). The bill was revised yet again on 22 June 2003 to make it more appealing to right-wing opposition, a strategy that seems to be necessary to gain support in the Senate.

Despite efforts to stall the bill in the Senate, in mid-2003, Republican Senator Ted Stevens of Alaska decided to cosponsor the bill with Senator Akaka. Stevens's support seems especially important given that he is chair of the US Senate Appropriations Committee and holds a lot of political sway. Jumping on the bandwagon, Republican Senator Gordon Smith from Oregon announced that he would lend his support, after Hawai'i Governor Linda Lingle met with him to discuss the proposal in late 2003 (Borreca 2003a). One other Republican senator also vowed his support as of December 2003-Orin Hatch of Utah. US Representative Ed Case, a Democrat from Hawai' $i$, has noted that he believes that support from the Bush administration is important to gaining federal recognition for Hawaiians, especially in the face of Republican opposition in the Senate (Arakawa 2003).

US Senator Daniel Inouye of Hawai'i (also a Democrat) explained the delay in passing the federal recognition legislation by pointing to the Senate being overwhelmed by appropriation bills (Viotti $2003 \mathrm{~b}$ ), which are no doubt linked to the US imperial presence in Iraq. Furthermore, Senator Inouye said it was his intent to push the bill through before the end of session in 2004. He also noted that political unity in Hawai'i-which includes support from Governor Linda Lingle, all of the state's mayors, county and state lawmakers, and the entire US congressional delegation 
- should go a long way in helping to secure Republican support in the Senate (Borreca 2003a, 2003 b; Viotti 2003 b). Lingle herself declared before the US Senate Committee on Indian Affairs that passage of the proposal was "vital to the continued character of our state, and it is vital to providing parity and consistency in federal policy for all native peoples in America" (Borreca 2003b). Still, as of July 2004, the Senate had not passed the bill.

During all of this political maneuvering, the Hawaiian people were left out of the fray. In response to this omission, the Office of Hawaiian Affairs launched a campaign to educate the people of Hawai' $i$ about issues relating to the legislation. According to OHA trustee Boyd Mossman (a retired Second Circuit Court judge), "OHA is now attempting to accomplish in two to three years what has not been accomplished in the last I Io years by achieving federal recognition and creating a governing entity for Hawaiians that will assist Hawaiians in defending against the equal-rights lawsuits pending in the federal courts. In this way, we believe we will be able to prevail in court and preserve not only the benefits and entitlements received by Native Hawaiians today, but also preserve the Hawaiian people and the Hawaiian culture" (Mossman 2003). He continued:

Hawaiians can survive as a unique people with federal recognition ...

If we fail, if we lose in the courts, if we cannot convince Congress of the potential elimination of an entire people who politically once ruled themselves, if we cannot convince the Hawaiians themselves and bring them together in a united effort, then you will have seen the last of the Hawaiians as we know them today. Hawaiians will be no different than Californians, Georgians, New Yorkers, etc. We will no longer be identified as the descendants of a once-proud nation with a unique history, language and identity. We will melt into history and become a memory only. The recognition, trust, benefits and entitlements heretofore provided the Hawaiian people will disappear, and oHA's trust fund, Hawaiian homelands, the many state and federally funded programs addressing significant needs of Hawaiians will be no more and will likely not be replaced by any state or charitable funding. (Mossman 2003)

Though his words resonated with many, Mossman was somewhat dismissive of those opposed to federal recognition on grounds that it will work against Hawai'i's national claims under international law. $\mathrm{He}$ asserted, "I am aware of those who rely on the United Nations and want only complete independence from the United States as well as those arguing equal rights who want an end to Hawaiian benefits, and I do not 
address these groups. They will not be interested in these words, and so I address those who must wonder what recognition, nationhood, cededlands settlement and equal rights for all [would mean]" (Mossman 2003).

In a contradictory rhetorical strategy, Mossman stressed the concept of political equality, which is already at odds with tribal sovereignty because federal recognition for Natives within US policy is not premised on equal treatment. In any case, opposition to the proposal goes beyond right-wing reluctance to pass the measure expanding Hawaiian rights that Mossman is addressing. As a result, some Hawaiians, along with others who support an independent Hawai'i and claims to nation-state status, have aligned themselves with Republican opposition, partaking in their language condemning the bill on the basis of "special rights" and "racial preferences." But those who support Hawai'i's independence from the United States have also pointed out problems with the proposal because of the limitations on Hawaiian sovereign expression.

\section{The Limits of Domestic Sovereignty: LESSONS FROM OTHER (IS)LANDS}

It is not at all clear that the passing of this bill would protect anything, given that the proposal itself, if passed, could be found to be unconstitutional, because any literal reading of the US Constitution would deem Hawaiians non-Indians. Hawaiians can look to cases from Indian Country and Native Alaska to shed light on the problems and pitfalls of federal recognition (Deloria and Lytle 1984). The proposal for Hawaiians is modeled on similar legal precedents for over three hundred federally recognized American Indian tribal nations. Yet, it seems more likely that this limited proposal would pave the way for an arrangement such as that of over 229 Alaska Native villages, which is currently in a precarious position. Alaskan Natives' federal recognition status shifted radically between the Clinton and Bush administrations. Under Clinton, they were listed on the federal register of federally recognized nations, a status that was challenged under Bush. ${ }^{17}$ Moreover, their political status was recently disputed, in the I998 US Supreme Court case of Alaska $v$ Native Village of Venetie Tribal Government, when the court ruled that Venetie's land base did not count as Indian Country in the legal sense. Because Indian Country is legally defined to include all dependent Indian communities in the United States, Venetie Village did not qualify, because their lands are not held in trust by the US federal government. Thus they cannot assess tax, 
enforce their own laws, or assert their jurisdiction over these lands as American Indian governments do on reservations. Moreover, the Alaska Native villages are subjected to Alaska state laws.

At the very most, the Hawaiian self-governing model proposed through the federal recognition process would allow for no more than a domestic dependent entity under the full and exclusive plenary power of Congress (Wilkins 1997). While US federal policy on Native Americans states that the federal government must consult with tribal governments regarding decisions about tribal lands, resources, and people, to honor the "government-to-government relationship," the US Congress has a long history of abusing its plenary power to subordinate tribal governments. Even worse, the US Congress most often delegates its power to agencies in the executive branch of the federal government, such as the Bureau of Indian Affairs within the Department of the Interior, which is directed by presidential appointees. To fully recognize Hawaiians as "Native Americans" having a political trust relationship with the United States similar to that of American Indians and Alaska Natives undercuts Hawaiian claims, particularly those to independent self-governance.

Because of the limits posed to independent national sovereignty under the proposed plan for federal recognition, dozens of Hawaiian sovereignty groups have persistently and consistently rejected the application of US federal Indian law that would recognize a Hawaiian domestic dependent nation-as ward to guardian - under the plenary power of Congress. Moreover, the exercise of federal plenary power not only comes from the Congress, the president, and the Department of the Interior-it also comes from the US Supreme Court, which has notoriously been ruling against tribal power for Indian nations and increasing the power of the states over them (Wilkins I997). The US Supreme Court construes the powers granted by the US Constitution to the Congress through its interpretation of the Indian Commerce clause of the Constitution. Through a series of precedents set by the rulings in Indian cases, the US Supreme Court has ruled time and time again that the federal government has exclusive power over Indian affairs (Wilkins I997).

The proposed legislation is a violation of both sovereignty and selfdetermination claims already acknowledged in the Apology Resolution. Given that Hawaiian Kingdom sovereignty was not lost via conquest, cession, or adjudication, those rights to self-rule are still in place under international law. Hawaiian people lost the ability to be self-determining through unilateral political processes-annexation and imposed statehood 
- but at no time did that amount to a legal termination of our inherent rights of sovereignty. Moreover, passage of the legislation could be used against Hawaiians and cited to show that claims that exceed the domestic sphere have been forfeited, especially since by then the Hawaiian governing entity would be subject to US plenary power. This containment of our sovereignty draws attention away from demands for Hawai'i's independence and decolonization from the United States, based on international law. While the history of the overthrow can justify the right of Hawaiians to federal recognition, that same history complicates any mode of sovereignty that is exclusively aboriginal, especially since citizenship under the Kingdom of Hawai'i was not limited to Hawaiians.

Hawaiian leaders of the various independence national initiatives argue that those most in support of federal recognition do not represent the Hawaiian people. Instead, those who work for the Office of Hawaiian Affairs, the Department of Hawaiian Home Lands, the Native Hawaiian Health Project, and other agencies represent the state, federal, and nonprofit organizations for whom they work, the same institutions that receive the funding being challenged in the courts. Therefore, supporting the proposal for federal recognition ensures their continued employment. On the other hand, the independence movement includes groups who advocate decolonization of Hawai'i from the United States or have selfproclaimed the restoration or continued existence of the Kingdom of Hawai'i. "They've got to deal with us sooner or later-it will come down to that," said activist Dennis "Bumpy" Kanahele, leader of the Nation of Hawai'i (quoted in Omandam 2003). Attorney and activist Ho'oipokalaena'auao Nakea Pa, of Ke Kia'i (the Native Hawaiian Advisory Council) asserted, "The problem now is, our voices are not being heard in Washington, and the resources and all the money is going into funding pro-Akaka (bill) efforts at the price of our potential rights to independence" (quoted in Omandam 2003). So not only have pro-independence Hawaiian voices been silenced, their opposition to the bill has been misrepresented as hostility to Hawaiian rights rather than protection of them.

In response to protests by those leading the struggle to restore Hawai'i's independence, OHA trustee Oswald Stender defended the proposal for federal recognition and argued that it would do nothing to prohibit claims beyond the federal model. He declared that "there are no guarantees and the Akaka Bill guarantees nothing. It does only two things: (I) it sets up the process for sovereignty and self-determination and (2) it gives recognition that the Hawaiians are the aboriginal people of this land" 
(e-mail posted to the KмA [Kanaka Maoli Allies] listserve, 7 Nov 2003). Yet, when one looks at the history of US federal recognition for indigenous domestic nations, it is clear that some guarantees do come along with the process. For example, the proposed legislation sets up a process to extinguish title to our Hawai'i's national lands-title that heretofore has not been relinquished, as realized in the US Apology Resolution. That is, once the bill sets up the process for the formation of a governing entity, approved by the US federal government, the Hawaiian government officials elected by Hawaiian people would be in a position to waive the rights and claims to independence under international law. In such a case, the will of the people would appear to have been expressed-as a form of self-determination in support of federal recognition-in a way that would make international intervention more implausible, especially while the US government would consider any Hawaiian question a domestic issue of internal self-determination within its nation-state.

Besides the cases of American Indians and Alaska Natives, there are lessons from other Pacific Islands. Two instructive examples are Guam and American Sāmoa, both of which are unincorporated US territories, organized and unorganized, respectively. Their histories shed light on the political limitations of domestic governing entities within the US nation-state. These two island entities are also subject to US congressional plenary power under the authority of the Territorial Clause of the US Constitution, as interpreted by the US Supreme Court. Therefore, legal cases move beyond the federal district courts anytime there is a question about their sovereign power. These are then adjudicated by the US Supreme Court under territorial case law, which upholds the doctrine that Guam and American Sāmoa are, along with Puerto Rico and the US Virgin Islands, "foreign in a domestic sense," not too different from tribal nations (Burnett and Marshall 200I). Even the Commonwealth of the Northern Mariana Islands is subject to exclusive congressional power by the United States and is working for an enhanced commonwealth status.

Cases of successful disentanglement do exist to which Hawaiians can turn as models. The only Island nations that have managed to extract themselves from the grip of US plenary power are those of the former UN Trust Territory of the Pacific Islands: the Republic of the Marshall Islands (RMI), the Federated States of Micronesia (FSM), and the Republic of Belau. For example, after the US government entered into political status negotiations with representatives of the peoples of the Federated States of Micronesia and the Marshall Islands, compacts of free association were 
signed in the Islands on I October 1982 and 25 June I983, respectively. In accordance with the Trusteeship Agreement, the Charter of the United Nations, and the stated objective of the Trust Territory system, the United States promoted the development of the peoples there toward self-government and independence according to the freely expressed wishes of the peoples themselves.

The compact was approved by majorities of the peoples of the Federated States of Micronesia and the Republic of the Marshall Islands in UN-observed plebiscites, conducted on 2 I June I983 and 7 September I983, respectively. Furthermore, the FSM and RMI governments were formed on island prior to any negotiation with the United States. The compact of free association was also approved by the FSM and RMI governments in accordance with their respective constitutional processes. Only after the FSM and RMI plebiscites was the compact approved as a joint resolution (Public Law 99-239) by the US Congress on I4 January 1986.

The process of the compact agreement is instructive for Hawaiians in that the order in which the political process unfolded in the Federated States of Micronesia and the Marshall Islands is strikingly different from the process in which the proposal for federal recognition of Hawaiians has taken place. In the case of the compact developments, there was a bilateral process guided by the United Nations. First they held meetings, and then the people approved the process. Next, prior to any negotiations with the United States, they formed new governments, and these governing bodies approved the compact proposals in accordance with their own constitutional processes. Then the US Congress passed the legislation.

The compact also delineated a section to protect the unadjudicated claims of the people of the Marshall Islands. For example, with regard to the lands on Ejit (a small island in Majuro Atoll), the compact stated that the president of the United States would negotiate an agreement with the government of the Marshall Islands, without prejudice regarding any claims that have been or may be asserted by any party as to rightful title and ownership of any lands on Ejit. If Hawaiians were to consider demanding a mutual-consent decree, to ensure bilateral agreements, a section could also be included to preserve their title to the so-called ceded lands- .8 million acres of former Crown and government lands of the Kingdom of Hawai'i. A request for a mutual-consent decree would certainly be telling for pro-federal recognition forces, since when Chamorro activists in Guam worked for the inclusion of a mutual-consent decree in 
their draft proposal for commonwealth status, the United States, through the Department of the Interior, rejected it entirely. That rejection indicates that the US government will continue to assert its plenary power over any model other than independence.

\section{Conclusion}

At the very least, those supporting federal recognition would do well to press for a plebiscite for Hawaiian people to vote on this model of sovereignty; then we would know for certain if it is the will of the people. It is one thing for those against independence to opt out of that model of sovereignty and pursue federal recognition. But whether people are informed as they make their way toward this goal remains a question in the minds of many.

Now more than ever, it seems, Hawaiians and others wishing to protect Hawai'i's national claims under international law must voice a resounding statement of refusal to consent. Those advocating for independence are divided between two central legal strategies: decolonization from the United States through UN protocols, and US de-occupation through protocols mandated by the laws of occupation (Kauanui forthcoming). In the case of unifying for the purposes of stopping federal recognition, the legacy of the I $897 \mathrm{Ku}$ ùe Petitions is instructive. As mentioned earlier, two different Hawaiian nationalist groups-Hui Aloha 'Āina and Hui Kālai'āina-widely opposed annexation. Hui Aloha 'Āina's petition unequivocally stated their resistance to US incorporation. The petition by Hui Kālai'āina went a step further by not only articulating their refusal of incorporation, but also demanding the restoration of the Kingdom. Although their goals differed, together they successfully defeated the I 897 Treaty of Annexation by demonstrating their lack of consent to becoming part of the United States. Perhaps a similar strategy of working across political differences for the purposes of stopping federal recognition could indefinitely defer the proposal for a Hawaiian nation within the US policy for Native Americans. That sort of alliance would surely be more effective than pro-independence factions aligning themselves with conservative forces in the US Senate for the purposes of stopping the bill.

It is true that prioritizing the independence claim in lieu of federal recognition will not serve to protect the US federal funding for Hawaiians now threatened by the lawsuits. But those worried primarily about protecting these funds should be urged to consider what they would be for- 
feiting in exchange for supporting the bill. While the federal-funding stream to the State of Hawai'i (for its agencies serving Hawaiians) is estimated at \$70 million per year-an amount that no doubt is crucial to alleviating Hawaiian suffering from the poverty and dispossession wrought by neocolonialism - that amount is only 0.7 percent of the state's entire annual budget. ${ }^{18}$ With these figures providing some perspective, it would seem that Hawaiians might have a better chance at de facto self-determination by remaining under the current state situation while pressing forward on international claims and resisting any US federal recognition that would foreclose our legitimate claims to independence.

* $* \quad *$

I WOULD FIRST LIKE TO THANK Circe Sturm for taking time to offer a critical reading of a draft of this article and for her friendship and colleagueship. This essay was supported by the Katrin H Lamon Fellowship at the School of American Research in Santa Fe, New Mexico, where I was in residence when I wrote it. Mahalo nui also to friends, comrades, and colleagues who continue to support my direction in terms of academic scholarship and who offered moral support for my work during the completion of this article: Lisa Kahaleole Hall, Anne Keala Kelly, Noenoe K Silva, and David Shorter.

\section{Notes}

I This quote from Queen Lili'uokalani (1964) was brought to my attention by my friend Anne Keala Kelly, who highlighted it in one of the first investigative journal reports about the proposal for Hawaiian federal recognition (Kelly 2002).

2 Interestingly, back in 1987 , the Hawaiian people organized into a sovereignty group called Ka Lāhui Hawai'i, with a membership roll of over 20,000 citizens, and initiated a proposal for federal recognition. But the Hawai' $i$ congressional delegation, including Senators Akaka and Inouye, were opposed to the plan, which leads people to wonder why they are so forcefully proposing it now. [For more about Ka Lāhui Hawai'i and sovereignty issues, see the interview with Mililani Trask, by Noe Noe Wong-Wilson, this issue, pages I 42-I 56 .]

3 One hundred years later, the United Nations issued the findings of a nineyear treaty study and called the annexation of Hawai'i into legal question (Omandam I998). More specifically, it assessed the so-called annexation as invalid.

4 With regard to the authority to acquire and establish interim governments for "acquired territories," Chief Justice Taney stated, in Dred Scott v John F A 
Sanford (I856): "There is certainly no power given by the Constitution to the Federal Government to establish or maintain colonies bordering on the United States or at a distance, to be ruled and governed at its own pleasure; nor to enlarge its territorial limits in any way, except by the admission of new States." Taney noted that "it has been held to authorize the acquisition of territory, not fit for admission at the time, but to be admitted as soon as its population and situation would entitle it to admission," and that the propriety of admitting a new state is made by the discretion of Congress, the way that Hawai'i became admitted as a state over six decades later, in 1959. See the legal opinion generated by the US Department of Justice in 1988: < http://hawaiiankingdom.org/legal-opinion-I988 .shtml>.

5 After a massive increase in American migration to Hawai' $i$, statehood emerged as a real prospect. As early as I950, two special elections were held to choose sixty-three delegates who would draft a state constitution for Hawai'i. In addition, among those who were allowed to take part in the vote were settlers as well as military personnel-who together outnumbered Hawaiians (Trask 1993).

6 Captain Cook first arrived in the island archipelago in 1778 ; thus that year marks a time prior to which it is assumed that no one other than Hawaiians was present in these Islands. Notably, the apology was not extended to non-Hawaiians who also endured the legacy of the overthrow-that is, those nonindigenous descendants of citizens of the Kingdom of Hawai' $i$.

7 For an analysis of what led to the 50 percent blood criterion, see Kauanui 1999, 2002.

8 However, it is also important to point out that data for Native Hawaiians, Samoans, and other Pacific Islanders have historically been subsumed within the pan-ethnic racial rubrics of "Asian and Pacific Islanders" and "Asian Pacific Islanders." This administrative practice has meant that all US data for Native Pacific Islanders have been disaggregated and lumped with those of Asian Americans. It also obscures both the differences between the Asian and the Native Pacific Islander subpopulations and the similarities in outcomes for Native Pacific Islanders, American Indians, and Alaska Natives. Hopefully, the new "Hawaiian and Other Pacific Islander" classification option provided in the 2000 US census will inspire the US Office of Management and Budget to direct agencies to collect meaningful racial data accordingly.

9 In all of these acts, Hawaiians are defined by the most inclusive definition: "any individual who is a descendent of the aboriginal people who, prior to 1778 , occupied and exercised sovereignty in the area that now constitutes the State of Hawai'i."

Io Some Hawaiian groups, including those pressing for federal recognition of a Native governing entity, submitted amicus curiae (friend of the court) briefs on behalf of the respondent. The State Council of Hawaiian Homestead Associations, Hui Kāko‘o ‘Āina Ho'opulapula, Kalama'ula Homestead Association, and 
the Hawaiian Homes Commission collectively submitted a brief. Another was collectively submitted by the Office of Hawaiian Affairs, Ka Lāhui, the Association of Hawaiian Civic Clubs, the Council of Hawaiian Organizations, the Native Hawaiian Convention, the Native Hawaiian Bar Association, the Native Hawaiian Legal Corporation, the Native Hawaiian Advisory Council, Hā Hawai' $i$, Hui Kālai'āina, Alu Like Inc, and Papa Ola Lōkahi. The Kamehameha Schools Bishop Estate Trust also offered amici curiae, as did the Hawai'i congressional delegation and the National Congress of American Indians. Moreover, the solicitor general at that time-Seth Waxman-also wrote a brief representing the Department of Justice in support of Cayetano. The governments of Alabama, California, Nevada, New Mexico, Oklahoma, Oregon, Washington, the Territory of Guam, and the Commonwealth of the Northern Mariana Islands did as well. It should not go unmentioned that among the amici curiae briefs for the petitioner, one was submitted from a Hawaiian group called Hou Hawaiians and a man named Maui Loa-who all identified themselves as "Native Hawaiian beneficiaries." They backed Rice and claimed that the Office of Hawaiian Affairs-by allowing Hawaiians who do not meet the 50 percent blood quantum rule to vote-violated the trust for those Hawaiians who do meet the criterion.

I I The court determined that it would subject the legislation in question to rational basis analysis rather than to strict scrutiny, dictating all other cases understood as race-based. In Adarand Constructors, Inc v Pena (I995), the Supreme Court ruled, "a group classification such as one based on race is ordinarily subjected to detailed judicial scrutiny to ensure that the personal right to equal protection of laws has not been infringed. Under this reasoning, even supposedly benign racial classifications must be subject to strict scrutiny.”

I 2 The perversion here is that Hawaiians-as a people-cannot press land claims against the state because of their wardship status.

I3 Justices Breyer and Souter concurred with the majority but took their opinion one step further, in that they denied the analogy between the relationship of Native Hawaiians to the US federal government and that of American Indians. In addition, they argued that there is no trust for Native Hawaiians and that the OHA electorate, defined by statute, did not sufficiently resemble an "Indian tribe."

I4 There are questions as to what the constitutional rights of US citizens who live in the US territories include. What are the rights and privileges of the residents (indigenous and nonindigenous) of these islands under the US Constitution and international law? Which provisions of the US Constitution apply in these islands? See Van Dyke I992.

I 5 Morton v Mancari (1974), the US Supreme Court case that upheld American Indian preferences as constitutional, established the precedent that the Fourteenth Amendment's equal-protection guarantees are not infringed by legislation that benefits American Indians because of their political relationship to the United States. But whether this case would be used regarding Hawaiians is debatable, 
because it is unclear what body of law the US Supreme Court would use to evaluate any Hawaiian cases in a post-federal recognition context. Moreover, whether the legislation for Hawaiian federal recognition would itself withstand a constitutional challenge has yet to be fully explored. The issue of whether the US Congress has the authority to enter into this sort of trust relationship with Hawaiians is dependent on authority under the Indian Commerce clause of the US Constitution. The US Department of Justice has not yet taken a position as to whether Hawaiians could fall under that clause for these purposes (Dunford 2003).

I6 See Morse I999; Pang I995; Hawaii Advisory Committee to the United States Commission on Civil Rights I99I; Faludi I99I; Federal-State Task Force on the Hawaiian Homes Commission Act I983; and Uyehara 1977.

I7 On I5 October I993, the Secretary of the Interior published a list of federally recognized tribes that included Alaska Native villages as tribal entities. The preamble read, "the villages and regional tribes [are] listed as distinctly Native communities and have the same status as tribes in the contiguous 48 states" (NARF I994). But there is currently a debate over Alaska Natives' legal status, as evinced in Republican Senator Ted Stevens's push to consolidate governmental funding for these entities into regional organizations, and in Don Mitchell's assertion that the Department of the Interior acted unlawfully when it put the villages on the federal list. See Indianz.com 2003.

I 8 The \$70-million-dollar figure is a high-end estimate put forth by the Council for Native Hawaiian Advancement-a pro-federal recognition consortium. The State of Hawai'i budget figures for 2003 can be found on the state budget/ fiscal website: <http://www.state.hi.us/budget/statefin/Supplemental\% $\%$ oBudget @ 2003-05/>

\section{References}

Arakawa, Lynda

2003 Bush Support Needed for Akaka Bill. Honolulu Advertiser, I3 August. Barayuga, Debra

20032 Defendants Dismissed from Hawaiian Programs Suit. Honolulu StarBulletin, 22 November. < http://starbulletin.com/2003/I I/22/news / story3.html>

Borreca, Richard

2003a Akaka Bill Gets Week of Lobbying. Honolulu Star-Bulletin, 23 February.

2003b Akaka Bill Gets Additional Support. Honolulu Star-Bulletin, Io December.

Burnett, Christina Duffy, and Burke Marshall

2001 Foreign in a Domestic Sense: Puerto Rico, American Expansion, and the US Constitution. Raleigh, NC: Duke University Press. 
Coffman, Tom

1998 Nation Within: The Story of America's Annexation of the Nation of Hawai $i$. Kenmore, wA: Epicenter.

Deloria Jr, Vine, and Clifford M Lytle

I984 The Nations Within: The Past and Future of American Indian Sovereignty. New York: Pantheon.

DePledge, Derrick

2003 Lawmakers Agree to Revise Hawaiian Recognition Bill. Honolulu Advertiser, I4 May.

Dunford, Bruce

2003 Federal Lawyers Take Up Legality of Akaka Bill. Honolulu StarBulletin, 25 July.

Faludi, Susan

I99I Broken Promise: How Everyone Got Hawaiians' Homelands Except the Hawaiians. Wall Street Journal, 9 September.

Federal-State Task Force on the Hawaiian Homes Commission Act

I983 Report to the United States Secretary of the Interior and the Governor of the State of Hawai'i. Honolulu: United States Department of the Interior. August.

Fuchs, Lawrence H

I96 I Hawaii Pono: A Social History. San Diego: Harcourt Brace Jovanovich. Hasager, Ulla, and Jonathan Friedman, editors

I994 Hawai $i$ : Return to Nationhood. IWgia Document 75. Copenhagen: International Working Group for Indigenous Affairs.

Hawai'i Advisory Committee to the United States Commission on Civil Rights I99I A Broken Trust: The Hawaiian Homelands Program: Seventy Years of Failure of the Federal and State Governments to Protect the Civil Rights of Native Hawaiians. Honolulu: Hawai'i Advisory Committee to the United States Commission on Civil Rights.

Indianz.com

2003 Alaska Natives Confront Debates Over Legal Status. 2I October. <http://www.indianz.com/News/archives/002 I07.asp>

Inouye, Daniel, Senator

2003 Hawaii Congressional Delegation Introduces Native Hawaiian Federal Recognition Bill. II February. <http://inouye.senate.gov/ inouye/ O3pr/200302 I I pro3.html>

Kauanui, J Kēhaulani

1999 "For Get" Hawaiian Entitlement: Configurations of Land, "Blood," and Americanization in the Hawaiian Homes Commission Act of 1920. Social Text 59:I 23-I 44.

2002 The Politics of Blood and Sovereignty in Rice $v$ Cayetano. Political and Legal Anthropology Review 25 (I): IOO-I28. 
forthcoming The Multiplicity of Hawaiian Sovereignty Claims and the Struggle for Meaningful Autonomy. In De-americanizing the Global? Critiques from Asia and the Pacific, edited by Ming-Bao Yue and Jon Gossman. Special Issue of Comparative American Studies 3 (I) [2005].

Kelly, Anne Keala

2002 The Akaka Bill and Hawaiian Self-determination. Honolulu Weekly, 30 January.

Kent, Noel

I993 Hawai ${ }^{i}$ : Islands Under the Influence. 2nd ed. Honolulu: University of Hawai'i Press.

Lili‘uokalani, $\mathrm{HRH}$

I964 Hawaii's Story by Hawaii's Queen. Rutland, vT: Charles E Tuttle Company. First published in I 898.

MacKenzie, Melody Kapilialoha, editor

I99I Native Hawaiian Rights Handbook. Honolulu: Native Hawaiian Legal Corporation and the Office of Hawaiian Affairs.

Morse, Harold

I999 Home Lands Lawsuit to Be Filed Today, Could Total \$roo Million. Honolulu Star-Bulletin, 29 December.

Mossman, Boyd P

2003 Hawaiians Can Survive as a Unique People with Federal Recognition. Maui News, 25 May.

NARF, Native American Rights Fund

I994 A Move Toward Sovereignty: Interior Publishes Alaska Tribe List. NARF Legal Review I9 (I) [Winter/Spring].

Omandam, Pat

I998 UN Report: Annexation Could Be Declared Invalid. Honolulu StarBulletin, I I August.

2002 Judge Denies Bid to End Native Hawaiian Funding. Honolulu StarBulletin, I3 March. <http://starbulletin.com/2002/03/13/news/story4 .html>

2003 Native Hawaiians Will Not Benefit by Bill, Say Some Sovereignty Groups. Honolulu Star-Bulletin, 25 February.

PIR, Pacific Islands Report

I999 Congressman Faleomavaega from American Samoa Expresses Concern over Potential US Supreme Court Ruling on Native Hawaiians case. 27 April. <http://I66.I22.I64.43/archive/I999/April/o4-29-I8.htm>

Pang, Gordon YK

I995 Land You Bought May Actually Be Home Lands. Honolulu StarBulletin, I7 February. 
Silva, Noenoe K

I998 Kanaka Maoli Resistance to Annexation. 'Ōiwi: A Native Hawaiian Journal I:40-80.

2004 Aloha Betrayed: Native Hawaiian Resistance to American Colonialism. Durham, NC: Duke University Press.

Trask, Haunani-Kay

I993 From a Native Daughter: Colonialism and Sovereignty in Hawai'i. Monroe, ME: Common Courage Press.

Uyehara, Mitsuo

I977 The Ceded Land Trusts, Their Use and Misuse. Honolulu: Hawaiiana Almanac Publishing Company.

Van Dyke, Jon $\mathrm{M}$

I992 The Evolving Relationship between the United States and Its Affiliated

Viotti, Vicki Flag States. University of Hawaii Law Review I4 (2): 445-502.

2003a Conservatives Blamed for Stalling Akaka Bill. Honolulu Advertiser, 29 August.

2003b Inouye: Maybe 2004 for Akaka Bill. Honolulu Advertiser, 30 August. Wilkins, David E

I997 American Indian Sovereignty and the US Supreme Court: The Masking of Justice. Austin: University of Texas Press.

Legal Cases

Adarand Constructors, Inc v Pena, 5I 5 US 200 (I995).

Alaska $v$ Native Village of Venetie Tribal Government, 522 US 520 (1998).

Bush v Gore, 53I US 98 (2000).

Dred Scott v John F A Sanford, 6o US 393 (I856).

Morton v Mancari, 4I7 US 535 (I974).

Rice v Cayetano, Governor of Hawaii, 528 US 495 (2000), I46 F3d I075, reversed.

\section{Abstract}

This essay examines the politics of the controversial proposal for US federal recognition for Native Hawaiians. It explores a range of historical and legal issues that shed light on the multiple claims that constitute the complex terrain of Hawaiian sovereignty politics. The article provides a historical overview of the events that impact the current situation and then discusses a particular set of contemporary conditions that serve as key elements in catalyzing widespread support for federal recognition-namely, the implications of the recent US Supreme Court 
ruling in Rice $v$ Cayetano and subsequent legal challenges to Native Hawaiian programs and funding by the US government. It also highlights difficulties with the promise of federal recognition as a solution to "the Hawaiian problem" by looking at lessons from Indian Country, Native Alaska, and the Pacific-especially the US unincorporated territories. Finally, the essay explores the independence movement as an alternative to domestic dependent nationhood.

KEYWORDS: Native Hawaiians, sovereignty, United States, federal recognition, indigenous politics, land, self-governance 